\title{
Letter to the Editor Concerning "Common
}

\section{Ophthalmic Preservatives in Soft Contact Lens Care Products: Benefits, Complications, and a Comparison to Non-Preserved Solutions" [Letter]}

\author{
Nir Erdinest ${ }^{\prime}$ \\ Naomi London (D) $^{2}$ \\ Nadav Levinger ${ }^{1,3}$ \\ 'Department of Ophthalmology, \\ Hadassah-Hebrew University Medical \\ Center, Jerusalem, Israel; ${ }^{2}$ Private \\ Practice, Jerusalem, Israel; ${ }^{3}$ Department \\ of Ophthalmology, Enaim Refractive \\ Surgery Center, Jerusalem, Israel
}

\section{Dear editor}

This letter is regarding the article titled "Common Ophthalmic Preservatives in Soft Contact Lens Care Products: Benefits, Complications, and a Comparison to NonPreserved Solutions". 1

We read this article with great interest and thank the authors for providing an excellent review on the current preservatives in multipurpose solution (MPS) products for soft contact lenses. In the interest of thoroughness, we would like to add a few factors not mentioned in the article which support the authors' conclusions advocating the use of non-preserved solutions.

Several in-vitro and in-vivo studies have demonstrated that multipurpose solutions (MPSs) containing polyquaternium-1 are inflammatory and induce oxidative stress to the ocular surface cells in various degrees. ${ }^{2}$ Furthermore, polyquaternium1 damage the barrier function of the corneal epithelial cells by affecting the localization of ZO-1 at tight junctions in response to Tumor Necrosis Factor Alpha (TNF- $\alpha$ ) secretion. ${ }^{2}$ Additional research has shown that certain MPSs containing PHMB and borate show amplified corneal staining and are injurious to comfortable soft contact lens wear, particularly in specific lens and solution combinations. $^{2}$

The authors highlight the complexity of the effect of preservatives in-vivo which can be influenced by the type of lens. As scleral lens wear has gained momentum around the globe, we would like to draw attention to the possible influence of these preservatives in that environment. While the accepted preferred recommendation is to fill the lens with unpreserved saline and disinfect with peroxide-based ( $\mathrm{H} 2 \mathrm{O} 2)$ products, ${ }^{3}$ many clinicians and patients have shifted from this formula to disinfecting with alternatives or using a more viscous fluid for lens filling. ${ }^{4}$ This modification is preferably also unpreserved, yet sometimes includes MPS formulas originally intended for soft lens use, in 3-7\% of wearers in one study. ${ }^{4}$ Reasons for this include wettability issues, or in an attempt to solve "midday fogging", caused by numerous possible etiologies. ${ }^{3,4}$ This can potentially elicit a corneal response. ${ }^{3}$ As mentioned in the article, the combination of ingredients in a solution and the combination of a solution with a particular lens material may
Correspondence: Naomi London Naomi Vision Boutique, 5 Even Israel, Jerusalem, Israel

Tel +972545406646

Fax +97225004333

Email imnl4u@gmail.com 
be pertinent to the development of corneal staining, or, as discussed in Alves et al, ${ }^{5}$ affect the optical properties of the lens. While it may not directly be a result exclusively of the preservative in the MPS and also associated with biochemical and biophysical interactions, the $\mathrm{H} 2 \mathrm{O} 2$ product was more resistant to change when combined with a variety of materials. ${ }^{5}$ Though these influences have not yet been examined in the scleral lens environment, they may or may not have clinical importance there as well. These considerations should evoke careful deliberation weighing the pros and cons carefully pending a recommendation to use an MPS with scleral lenses.

\section{Funding}

The authors of this letter did not receive any specific grant from funding agencies in the public, commercial, or notfor-profit sectors.

\section{Disclosure}

The authors have no conflicts of interest to declare for this communication.

\section{References}

1. Bradley CS, Sicks LA, Pucker AD. Common ophthalmic preservatives in soft contact lens care products: benefits, complications, and a comparison to non-preserved solutions. Clin Optom. 2021;13:271. doi: $10.2147 /$ OPTO.S235679

2. Oh S, McCanna DJ, Subbaraman LN, Jones LW. Cytotoxic and inflammatory effects of contact lens solutions on human corneal epithelial cells in vitro. Cont Lens Anterior Eye. 2018;41 (3):282-289. doi:10.1016/j.clae.2017.12.006

3. Barnett M, Courey C, Fadel D, et al. CLEAR-Scleral lenses. Cont Lens Anterior Eye. 2021;44(2):270-288.

4. Schornack MM, Fogt J, Nau A, et al. Scleral lens prescription and management practices: emerging consensus. Cont Lens Anterior Eye. 2021:101501. doi:10.1016/j.clae.2021.101501

5. Alves M, Castanheira EM, Lira M. Interactions between contact lenses and lens care solutions: influence in optical properties. Cont Lens Anterior Eye. 2021;44(5):101414. doi:10.1016/j.clae.2021.01. 009

\footnotetext{
Dove Medical Press encourages responsible, free and frank academic debate. The content of the Clinical Optometry 'letters to the editor' section does not necessarily represent the views of Dove Medical Press, its officers, agents, employees, related entities or the Clinical Optometry editors. While all reasonable steps have been taken to confirm the content of each letter, Dove Medical Press accepts no liability in respect of the content of any letter, nor is it responsible for the content and accuracy of any letter to the editor.
}

\section{Publish your work in this journal}

Clinical Optometry is an international, peer-reviewed, open access journal publishing original research, basic science, clinical and epidemiological studies, reviews and evaluations on clinical optometry. All aspects of patient care are addressed within the journal as well as the practice of optometry including economic and business analyses. Basic and clinical research papers are published that cover

Submit your manuscript here: https://www.dovepress.com/clinical-optometry-journal all aspects of optics, refraction and its application to the theory and practice of optometry. The manuscript management system is completely online and includes a very quick and fair peer-review system, which is all easy to use. Visit http://www.dovepress.com/ testimonials.php to read real quotes from published authors. 